\title{
THE RELATIONSHIP BETWEEN BUILT-UP AREAS AND THE SPATIAL DEVELOPMENT OF THE MEAN MAXIMUM URBAN HEAT ISLAND IN DEBRECEN, HUNGARY
}

\author{
ZSOLT BOTTYÁN, ${ }^{\mathrm{a}, *}$ ANDREA KIRCSI, ${ }^{\mathrm{b}}$ SÁNDOR SZEGEDI ${ }^{\mathrm{b}}$ and JÁNOS UNGER \\ a Department of Resource Management, University of Debrecen, Böszörményi str. 138, 4032 Debrecen, Hungary \\ b Department of Meteorology, University of Debrecen, PO Box 13, 4010 Debrecen, Hungary \\ c Department of Climatology and Landscape Ecology, University of Szeged, PO Box 653, 6701 Szeged, Hungary
}

\author{
Received 26 March 2004 \\ Revised 3 November 2004 \\ Accepted 3 November 2004
}

\begin{abstract}
The climate of built-up regions differs significantly from rural regions and the most important modifying effect of urbanization on local climate is the urban temperature excess, otherwise called the urban heat island (UHI).

This study examines the influence of built-up areas on the near-surface air temperature field in the case of the mediumsized city of Debrecen, Hungary. Mobile measurements were used under different weather conditions between March 2002 and March 2003. Efforts concentrated on the determination of the spatial distribution of mean maximum UHI intensity with special regard to land-use features such as built-up ratio and its areal extensions.

In both (heating and non-heating) seasons the spatial distribution of the UHI intensity field showed a basically concentric shape with local anomalies. The mean maximum UHI intensity reaches more than $2.0^{\circ} \mathrm{C}$ (heating season) and $2.5^{\circ} \mathrm{C}$ (non-heating season) in the centre of the city. We established the relationship between the above-mentioned land-use parameters and mean maximum UHI intensity by means of multiple linear regression analysis. As the measured and predicted mean maximum UHI intensity patterns show, there is an obvious connection between the spatial distribution of urban thermal excess and the land-use parameters examined, so these parameters play a significant role in the development of the strong UHI intensity field over the city. Copyright (C) 2005 Royal Meteorological Society.
\end{abstract}

KEY WORDS: UHI; spatial and seasonal patterns; built-up ratio; grid network; statistical analysis; regression equations; Debrecen, Hungary

\section{INTRODUCTION}

The temperature excess of cities that is caused by urbanization (the so-called urban heat island (UHI)) is a well-known and thoroughly researched phenomenon of urban climatology. In certain cities of the temperate climatic zone, structures and features of the UHI are well documented. (e.g. Landsberg, 1981; Kuttler, 1998). In the case of Debrecen and Szeged, Hungary, preliminary observations have proved the existence of the UHI and also provided information on its spatial structure (e.g. Unger, 1999; Szegedi, 2000; Unger et al., 2001a,b; Kircsi and Szegedi, 2003; Szegedi and Kircsi, 2003).

One of the most interesting aspects of the UHI is its peak development during the diurnal cycle and its connection with the different urban surfaces. This relationship means that the simulation of real factors and physical processes of development of maximum UHI is difficult, as the generally complicated urban surface geometry with often irregular (highly varied) built-up characteristics, the different building materials, the considerable artificial heat production and the air pollution significantly modify the radiation and energy balances.

* Correspondence to: Zsolt Bottyán, Department of Resource Management, University of Debrecen, Fürt str. 4, 5008 Szolnok, Hungary; e-mail: zbottyan@mail.externet.hu; zbottyan@helios.date.hu 
Despite these difficulties, there are several models for studying small-scale climatic variations within the cities based on the energy balance (Tapper et al., 1981; Johnson et al., 1991; Myrup et al., 1993; Ruffieux, 1995), radiation (Voogt and Oke, 1991), heat storage (Grimmond et al., 1991), water balance (Grimmond and Oke, 1991) and surface sensible heat flux (Voogt and Grimmond, 2000) approaches.

Statistical models may also provide useful quantitative information about spatial features of the maximum UHI intensity by employing different urban surface parameters (e.g. Outcalt, 1972; Oke, 1981, 1988; Park, 1986; Kuttler et al., 1996; Matzarakis et al., 1998; Unger et al., 2000; Bottyán and Unger, 2003).

In this paper, the spatial distribution of the seasonal mean maximum UHI intensity is presented for the city of Debrecen. Then, the connection between the built-up surface parameter and mean maximum UHI intensity is examined and determined. Finally, a linear statistical model is constructed to estimate the spatial distribution of the thermal excess for the study area, based on built-up (covered surface) ratio.

\section{STUDY AREA AND METHODS}

\subsection{Study area}

Debrecen $\left(47.5^{\circ} \mathrm{N}, 21.5^{\circ} \mathrm{E}\right)$ lies at a height of $120 \mathrm{~m}$ above sea level on nearly flat terrain in the Great Hungarian Plain that is favourable for UHI development (Figure 1). It is the second largest city in Hungary and has a population of 220000 . Debrecen is the cultural, academic and economic centre of the northeastern region of the country.

The city and its environment belong to Köppen's climate region Cfb on the basis of the 1961-90 climate normal (Table I), but the climate in the Carpathian basin shows a significant year-by-year fluctuation. In particular, there are extreme fluctuations in the amount of precipitation, which often causes considerable

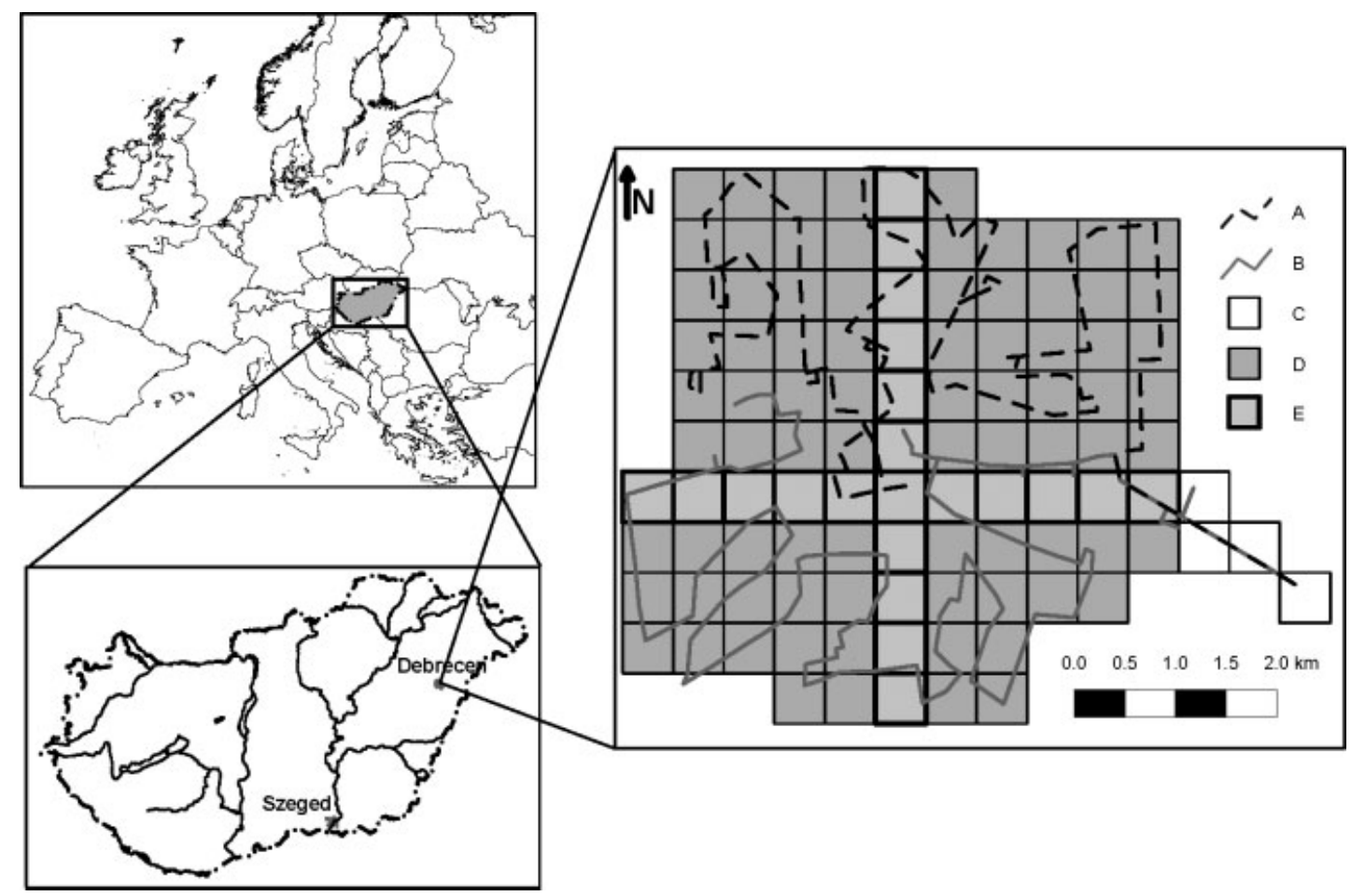

Figure 1. Location of the study area (A: route of the measurements in the northern sector of the grid network; B: route of the measurements in the southern sector of the grid network; C: grid network for UHI measurements in Debrecen; D: cells used for the construction of the statistical model; E: cells used for cross-sections) 
Table I. Annual and monthly means and sums of meteorological parameters at Debrecen airport, 1961-90 (Anon., 1992)

\begin{tabular}{lc}
\hline Temperature $\left({ }^{\circ} \mathrm{C}\right)$ & 9.9 \\
Temperature range $\left({ }^{\circ} \mathrm{C}\right)$ & 22.9 \\
January temperature $\left({ }^{\circ} \mathrm{C}\right)$ & -2.6 \\
July temperature $\left({ }^{\circ} \mathrm{C}\right)$ & 20.3 \\
Precipitation $(\mathrm{mm})$ & 566 \\
Wind $\left(\mathrm{m} \mathrm{s}^{-1}\right)$ & 2.8 \\
Sunshine duration $(\mathrm{h})$ & 1982 \\
\hline
\end{tabular}

problems for agriculture in the region. The annual amount of precipitation is about $550 \mathrm{~mm}$. The annual variation of precipitation shows a maximum in May and June. Generally, the summer is sunny and warm, with an average temperature above $20^{\circ} \mathrm{C}$. The winter is cold; it is around $-2{ }^{\circ} \mathrm{C}$ and it is often snowy. The annual temperature range is more than $20^{\circ} \mathrm{C}$ because of the continental influence on the climate of the eastern region of Hungary. The annual mean temperature is almost $10^{\circ} \mathrm{C}$. The wind speed is usually around $3 \mathrm{~m} \mathrm{~s}^{-1}$ and the prevailing wind direction is northeasterly.

The year can be divided into two from the point of view of city dwellers and their activities: the heating (from October until April) and the non-heating (from April until October) seasons.

The main part of the city was divided into grids of $500 \times 500 \mathrm{~m}^{2}$; thus, it contains 105 cells $\left(26.25 \mathrm{~km}^{2}\right)$ altogether (Figure 1). The grid network itself was established by sub-dividing the $1 \mathrm{~km} \times 1 \mathrm{~km}$ square network of the Unified National Mapping System (in Hungarian: EOTR) developed for the topographical maps of Hungary (Unger et al., 2000, 2001a,b). Because of the gaps in the original dataset of the built-up parameter we omitted the four southeastern cells from the investigation, so the present study applies only to 101 grid cells (Figure 1).

\subsection{UHI measurements}

In order to acquire data on the spatial distribution of the near-surface air temperature, measurements were carried out on about 10-day intervals under various synoptic weather conditions (except precipitation, which eliminates the small-scale modifying effects of the surface; Szegedi and Kircsi, 2003). The temperature data were collected by mobile observations during the period between March 2002 and March 2003. In the case of surface temperature and near-surface air temperature, as well as for other urban parameter measurements, traverses with different vehicles (car, tram, helicopter, airplane, satellite) are a common process (e.g. Oke and Fuggle, 1972; Johnson, 1985; Park, 1986; Moreno-Garcia, 1994; Eliasson, 1996; Yamashita, 1996; Voogt and Oke, 1997; Comrie, 2000; Grimmond et al., 2001). The UHI intensity (namely $\Delta T$, the temperature difference between urban and rural areas) was measured in every cell, on fixed return routes. A total of 32 traverses were taken in the area investigated during the 1 year study period: 15 in the non-heating season and 17 in the heating season. This frequency of mobile observations provided sufficient information on different weather conditions, except precipitation (Table II). As Table II shows the temperature varied between $-14.3^{\circ} \mathrm{C}$ and $+29.9^{\circ} \mathrm{C}$ during the measurements, and both low and high values occurred. The maximum wind speed was $6 \mathrm{~m} \mathrm{~s}^{-1}$ and values higher than $3 \mathrm{~m} \mathrm{~s}^{-1}$ were observed altogether five times (less than $16 \%$ of the 32 events) in the period investigated; thus, we can state that the weather situations were generally calm on these days. The cloudiness varied between 0 and 8 octas. The distribution of this parameter was mainly regular: 13 days had 0-2 octas, 5 days had 3-5 octas and 11 days had 6-8 octas cloudiness during the measurements. So our temperature (UHI intensity) values were measured under different weather conditions, except for precipitation and high wind speed, which are not favourable for the development of the UHI.

Because of the expected dense data information on the temperature, two measurement sectors were established in the study area. Thus, there are return routes of $62.5 \mathrm{~km}$ and $57.3 \mathrm{~km}$ in length, based on the street network of the city, in the northern and the southern sectors respectively. Because of the large 
Table II. Observed meteorological parameters during the UHI measurements at the weather station of the University of Agriculture of Debrecen

\begin{tabular}{|c|c|c|c|c|c|}
\hline \multirow[t]{2}{*}{ Measurement date } & \multicolumn{2}{|c|}{ Air temperature $\left({ }^{\circ} \mathrm{C}\right)$} & \multirow[t]{2}{*}{ Cloudiness 19:00 (octas) } & \multicolumn{2}{|c|}{ Wind speed $\left(\mathrm{m} \mathrm{s}^{-1}\right)$} \\
\hline & $19: 00$ & $01: 00$ & & $19: 00$ & $01: 00$ \\
\hline \multicolumn{6}{|l|}{2002} \\
\hline 06 March & 11.1 & 8.4 & 6 & 2 & 5 \\
\hline 14 March & 10.9 & 6.8 & 0 & 2 & 2 \\
\hline 05 April & 2.8 & 1.4 & 7 & 5 & 4 \\
\hline 15 April & 13.2 & 6.4 & 8 & 2 & 1 \\
\hline 06 May & 15.9 & 8.1 & 7 & 2 & 0 \\
\hline 15 May & 17.2 & 14.1 & 5 & 2 & 2 \\
\hline 23 May & 22.0 & 16.6 & 5 & 2 & 2 \\
\hline 04 June & 16.3 & 11.2 & 7 & 2 & 0 \\
\hline 13 June & 22.4 & 16.4 & 6 & 3 & 2 \\
\hline 26 June & 21.2 & 12.0 & 0 & 3 & 2 \\
\hline 05 July & 20.4 & 13.9 & 2 & 4 & 3 \\
\hline 15 July & 29.9 & 21.5 & 2 & 1 & 3 \\
\hline 24 July & 22.6 & 18.5 & 3 & 2 & 1 \\
\hline 21 August & 19.7 & 12.2 & 2 & 0 & 2 \\
\hline 27 August & 20.2 & 16.3 & 1 & 2 & 1 \\
\hline 02 September & 16.3 & 13.9 & 1 & 5 & 4 \\
\hline 18 September & 15.1 & 11.6 & 3 & 2 & 1 \\
\hline 07 October & 6.0 & 2.6 & 7 & 1 & 2 \\
\hline 14 October & 7.2 & 6.4 & 7 & 1 & 0 \\
\hline 12 November & 3.3 & 1.0 & 4 & 2 & 3 \\
\hline 18 November & 12.1 & 8.6 & 0 & 3 & 3 \\
\hline 27 November & 5.6 & 1.9 & 6 & 1 & 1 \\
\hline 12 December & -8.5 & -5.6 & 0 & 1 & 3 \\
\hline \multicolumn{6}{|l|}{2003} \\
\hline 27 January & -2.7 & -0.8 & 8 & 2 & 2 \\
\hline 02 February & -8.2 & -8.4 & 7 & 1 & 2 \\
\hline 17 February & -7.6 & -8.2 & 0 & 2 & 4 \\
\hline 18 February & -4.4 & -5.4 & 0 & 5 & 6 \\
\hline 24 February & -9.5 & -14.3 & 0 & 1 & 1 \\
\hline 26 February & -9.0 & -11.6 & 0 & 5 & 2 \\
\hline 05 March & -1.0 & -2.4 & 8 & 1 & 2 \\
\hline 24 March & 7.5 & 2.6 & 0 & 2 & 2 \\
\hline 25 March & 8.5 & 5.5 & 0 & 1 & 2 \\
\hline
\end{tabular}

number of cells, the time difference between the first and the last grid along the routes was about $90 \mathrm{~min}$, which is a considerable time span for the temperature change in different parts of the city. For this reason, to obtain comparable temperature data during the measurements, we visited each grid first on the way to the end of the route and for the second time on the way back. Having averaged the measurement values by cells, time adjustments to a reference time (namely the likely time of the occurrence of the strongest UHI in the diurnal course) were applied, assuming a linear air temperature change with time. The linear adjustment appears to be correct for data gathered a few hours after sunset in urban areas. However, because of the different time variations of cooling rates, it is only approximately correct for suburban and rural areas (Oke and Maxwell, 1975). The reference time was $4 \mathrm{~h}$ after sunset, since the heat island intensity reaches its maximum 3-5 h after sunset (Landsberg, 1981; Unger et al., 2001). Consequently, in a given measuring night we can assign one temperature value to every cell in the northern sector or in the southern sector. These values refer to the centre of each cell. 
Digital temperature sensors (LogIT HiTemp, resolution of $0.1^{\circ} \mathrm{C}$ ) were mounted at $0.6 \mathrm{~m}$ in front of the cars at a height of $1.7 \mathrm{~m}$ above ground level. The thermometers had a thermal shield to eliminate the radiant heat from the cars' engines. The data were recorded on LogIT SL dataloggers, which were located inside the cars. The sampling interval was $10 \mathrm{~s}$, so at a car speed of $20-30 \mathrm{~km} \mathrm{~h}^{-1}$ the average distance between the measuring points was $55-83 \mathrm{~m}$. This car speed was sufficient to provide adequate ventilation for the sensor to measure the momentary ambient air temperature. The traffic density was low due to the measurements taking place late at night. The logged values at forced stops and for a few cases that were too close to the rear part of the vehicles in front were deleted from the data set.

The determination of the urban-rural air temperature differences $\Delta T$ of cells was based on the reference to the temperature of the easternmost cell of the original study area, which was regarded as a rural one because of it being located outside of the city (Figure 1). The 105 (now 101) points that cover the urban parts provide an appropriate basis to interpolate isolines using the standard kriging procedure. The pattern of isotherms provides us with a detailed picture on the average thermal field within the city at the time of the strongest effects of urban factors in both study periods (Figure 2).

\subsection{Built-up ratio}

The built-up characteristics of the city play a significant role in the development of the UHI (e.g. Park, 1986; Eliasson, 1996; Goh and Chang, 1999; Montavez et al., 2000). Generally, the distribution of the urban surface parameters changes slowly in time, so we can consider them as being quasi-invariable factors. For UHI investigations it is important to have information on the spatial distribution of the surface parameters, which essentially determine the spatial development of the temperature excess (Unger et al., 2000; Bottyán and Unger, 2003). On the other hand, the spatial and temporal characteristics of the UHI field depend on both urban parameters and meteorological conditions. On the basis of their special built-up characteristics, the UHI pattern is always different for every city.

One of the most relevant factors of the urban surface is the amount of artificial surface cover (the builtup ratio). In our investigation, a crucial point was to determine this land-use parameter for all cells in Debrecen. The method was applied in some urban climate studies of Szeged using SPOT XS satellite images (Mucsi, 1996; Unger et al., 2000, 2001a), but in the case of Debrecen, contrary to Szeged, LANDSAT TM (28 June 1992) imagery was used. The vector and raster-based geographical information system database was developed at the University of Szeged in the Applied Geoinformatics Laboratory. The digital satellite image was calibrated to the EOTR using 1:10000 scale maps. The nearest-neighbour method of resampling was employed and the resolution of the image was $20 \mathrm{~m} \times 20 \mathrm{~m}$, so small urban units could be assessed independently of their larger scale official land-use classification.

The normalized difference vegetation index (NDVI) was calculated from the pixel values in the near-infrared (IR: $0.72-1.1 \mu \mathrm{m})$ and visible red $(R: 0.58-0.68 \mu \mathrm{m})$ bands (Gallo and Owen, 1999):

$$
\mathrm{NDVI}=\frac{\mathrm{IR}-R}{\mathrm{IR}+R}
$$

NDVI values vary between -1 and +1 , indicating the effect of green space in the units of $20 \mathrm{~m} \times 20 \mathrm{~m}$. Built-up, water and vegetated surfaces were distinguished according to their NDVI values. In the area of Debrecen investigated, the occurrence of non-vegetated (bare) areas is negligible, i.e. each open space is covered by some vegetation (e.g. gardens and cultivated plants, trees, grass, bushes, weeds). The ratios (to total cell area) of these land-use types for each grid element were determined using cross-tabulation.

\subsection{Construction of the statistical model}

In one of our previous studies, a strong linear connection was demonstrated between the built-up ratio and Szeged's mean maximum UHI intensity, which has a size and population similar to that of Debrecen. In addition, there was also a relationship between the distance from the city centre and UHI intensity in Szeged (Unger et al., 2000). 

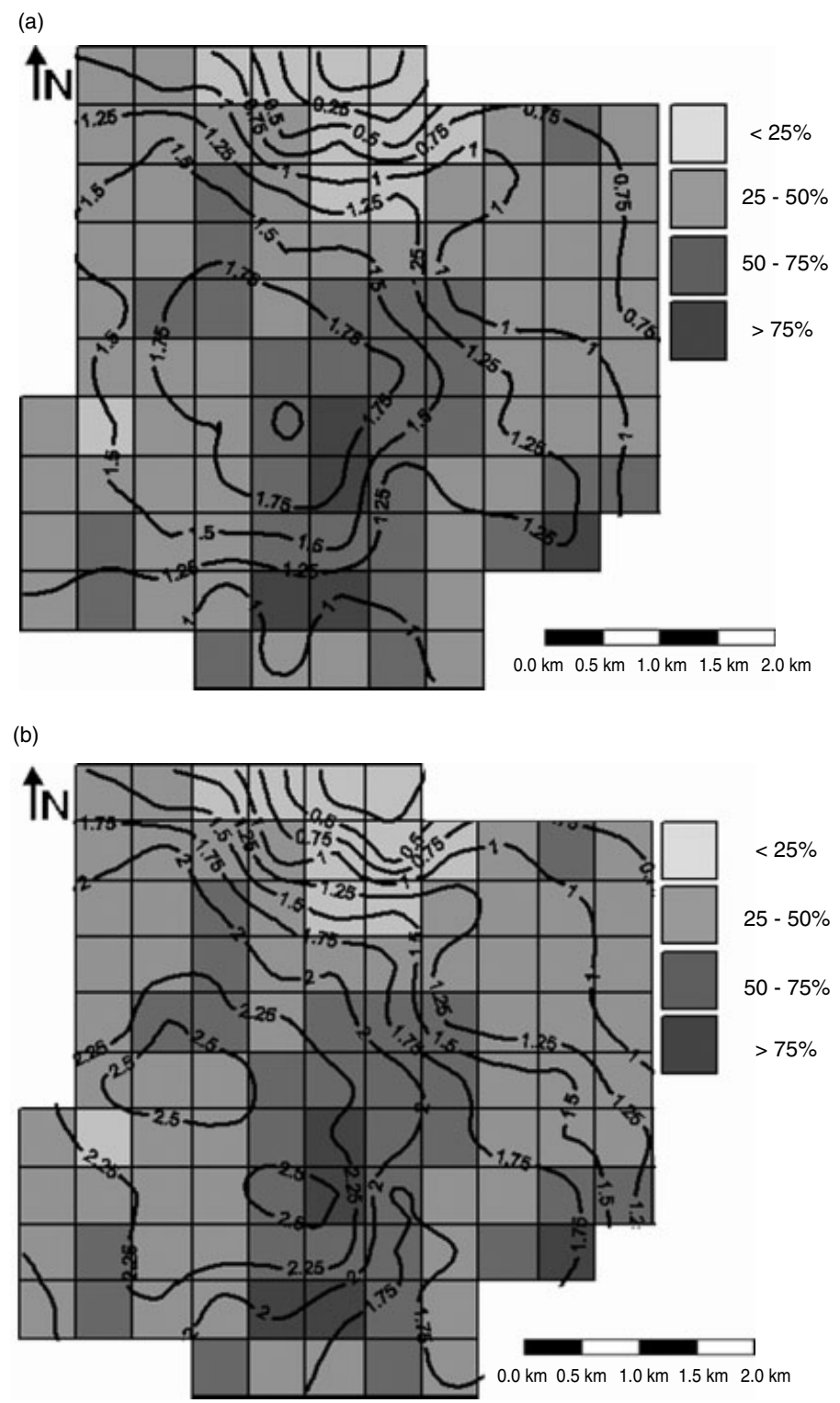

Figure 2. Spatial distribution of the mean maximum UHI intensity $\left({ }^{\circ} \mathrm{C}\right)$ and the built-up ratio $(\%)$ in Debrecen: (a) heating season; (b) non-heating season

In the case of Debrecen we also found two significant relationships between the urban surface parameters, similar to the above-mentioned ones, in both seasons (Figures 3 and 4). However, the linear connections between distance and UHI intensity were stronger in Szeged because this city has an almost concentric shape and built-up characteristics $(r=0.748$ and $r=0.814$ in Szeged in the heating and non-heating seasons respectively as well as $r=0.630$ and $r=0.437$, in Debrecen in the same seasons). Apparently, these $r$ values are low in Debrecen, but we have to consider the large number of grid cells $(n=101)$. If the element number were equal to 100 then the $99 \%$ significance level of $r$ would be 0.25 , so all of the above-mentioned correlation coefficients are significantly higher than this one. On the other hand, applying the distance parameter as a crucial predictor in our statistical model leads to problems in the case of less-concentric cities, because the model performance for such cities is likely to be poor. In addition, the straightforward 

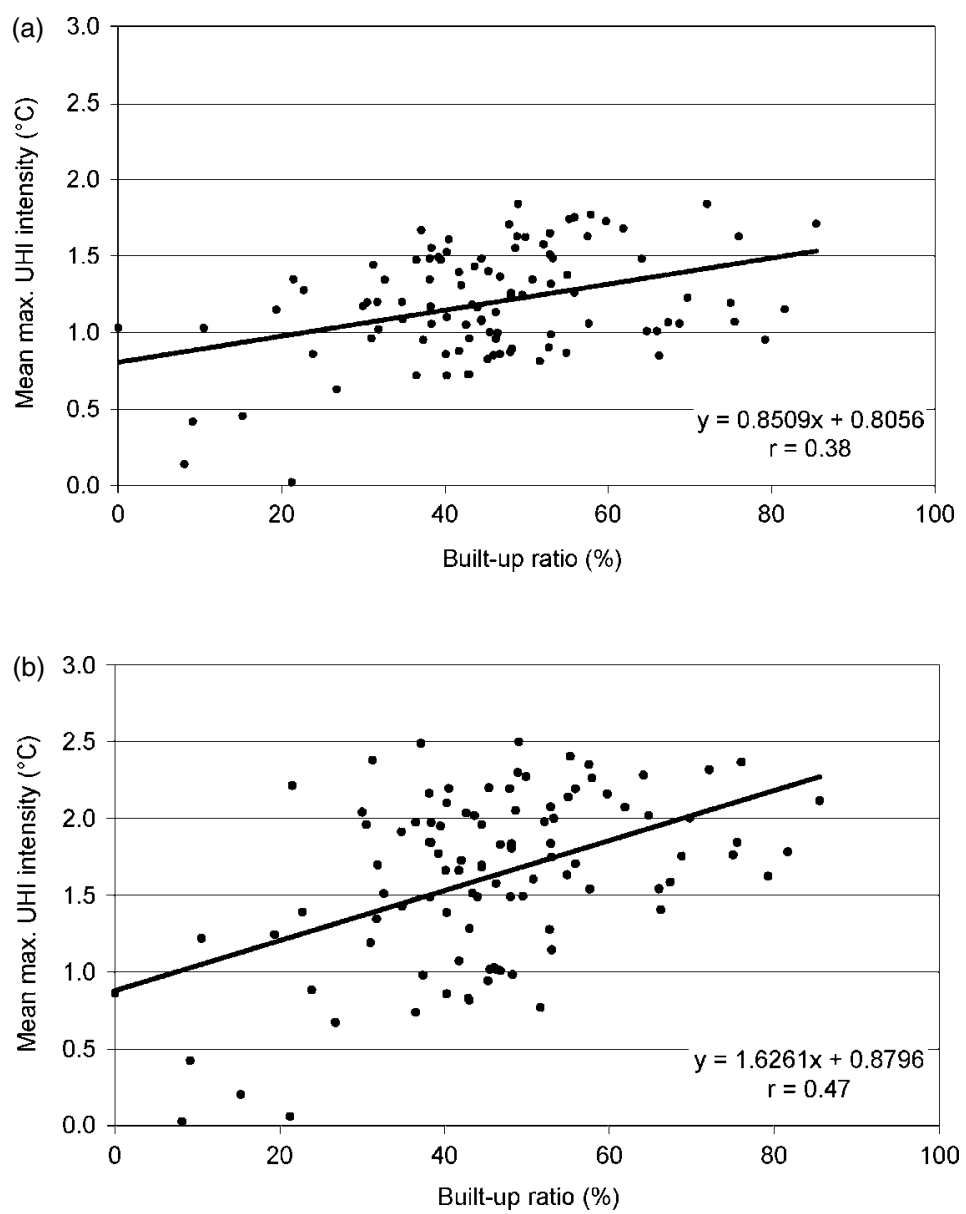

Figure 3. Connection between the mean maximum UHI intensity and the built-up ratio in Debrecen: (a) heating season; (b) non-heating season

use of distance from the centre as a linear predictor would also cause a negative UHI intensity at some outer parts of the city, which would generally be a nonsense value. All the same, the relationship between distance and UHI intensity is a real and important connection, so we built it into our model on the basis of the following method.

Regarding the above-mentioned facts, in the course of determination of the model equations, we used the seasonal mean maximum values of UHI intensity $\Delta T$ and the previously mentioned land-use parameter, i.e. ratio of built-up surface $B$ as a percentage by cells. Since $B$ changes rapidly with increasing distance from the city centre, we applied the exponentially distance-weighted spatial means of this parameter for our model. The distance scale of the weight should be derived from the transport scale of heat in the urban canopy. Our statistical model has determined this scale from the measured parameter values.

In compliance with this, a set of predictors can be determined concerning the surface built-up ratio and its areal extensions in the following way:

- parameter value in the grid cell $B$ with $\Delta i^{2}+\Delta j^{2}=0$

- mean parameter value of all grid cells $B_{1}$ with $0<\Delta i^{2}+\Delta j^{2}<2^{2}$

- mean parameter value of all grid cells $B_{2}$ with $2^{2} \leq \Delta i^{2}+\Delta j^{2}<4^{2}$

- mean parameter value of all grid cells $B_{3}$ with $4^{2} \leq \Delta i^{2}+\Delta j^{2}<8^{2}$ 

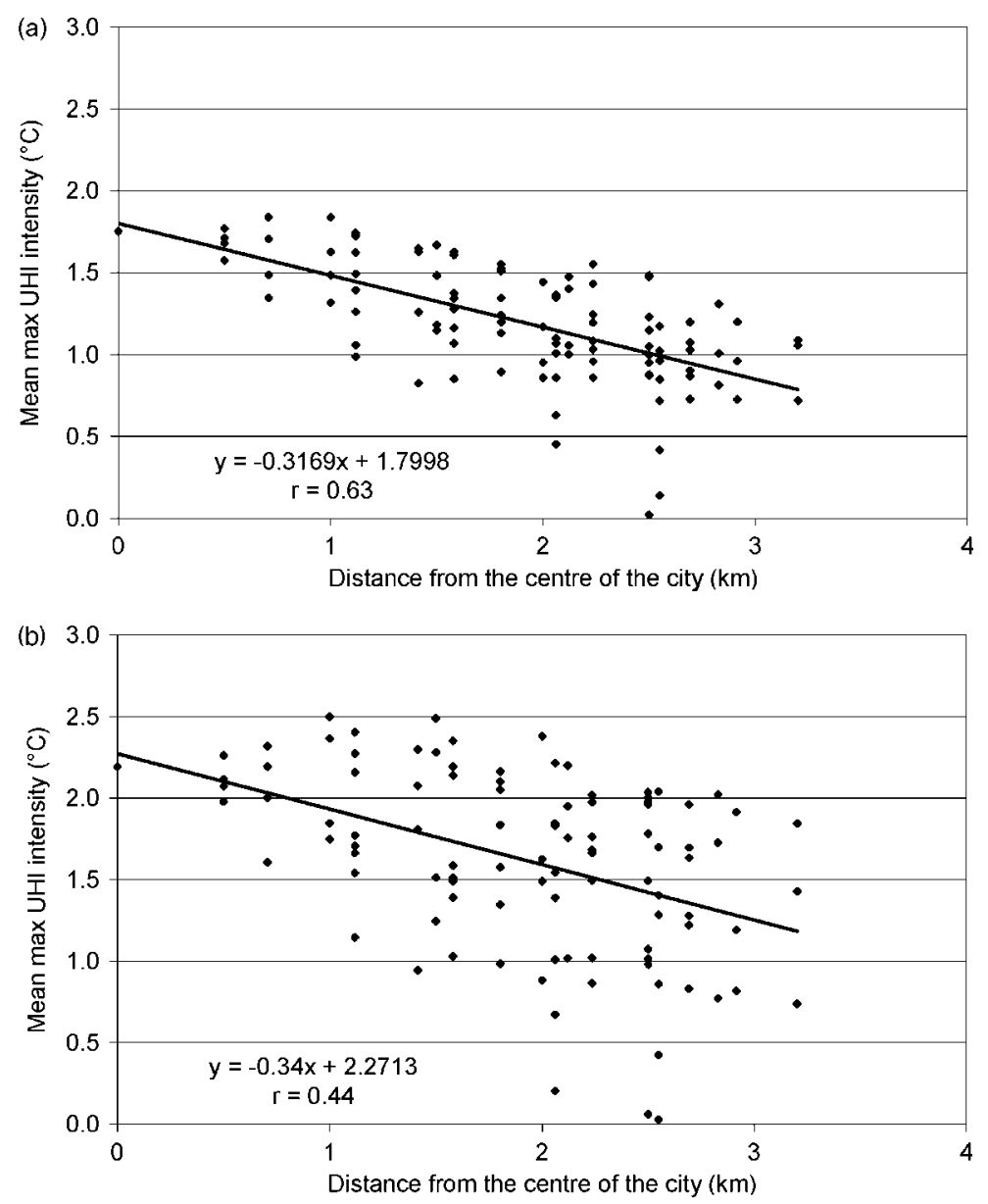

Figure 4. Connection between the mean maximum UHI intensity and the distance from the centre in Debrecen: (a) heating season; (b) non-heating season

Here, $i$ and $j$ are cell indices in the two dimensions, and $\Delta i$ and $\Delta j$ are the differences of grid cell indices with respect to a given cell. These zones cover the entire model (investigated) area of Debrecen. Now we have four predictors to build a linear statistical model. This procedure creates the right conditions for applying our model to predict the UHI intensity in other cities with a different size and non-concentric shape.

The model construction method chosen was stepwise multiple linear regression. The implementation of this procedure can be found in the SPSS 11 computer statistics software. A comprehensive discussion of the mathematical background of the method is given by Miller (2002). Predictors were entered or removed from the model depending on the significance of the $F$ values 0.05 and 0.1 respectively. Under these conditions, two linear statistical model equations were determined according to the separately investigated heating and non-heating seasons, because there is a very noticeable difference between the magnitudes of UHI intensity fields in these seasons.

\section{RESULTS AND DISCUSSION}

\subsection{Built-up characteristics of the study area and the UHI}

The spatial distribution of the built-up ratio in the study area has some important properties, as discussed below. 
(1) Values of built-up ratio increase from the edges towards the central part of the urban areas. This means that the city has, to a certain degree, a concentric-like shape (Figure 2). Near the geometrical centre of the city the ratio of the artificial surface cover is the highest (the extreme value is $86 \%$ ) and the average distance between buildings is the shortest. However, the highest buildings can mainly be found in the housing estates in the western and northwestern parts of the city and not in the centre.

(2) The above-mentioned increase depends greatly on the direction, so there are local irregularities in the builtup ratio field in the city (Figure 2). In order to demonstrate the change of the direction-dependent varieties of artificial surface cover and the mean maximum UHI intensity, we made two cross-sections within the study area. The $\mathrm{S}-\mathrm{N}$ and $\mathrm{W}-\mathrm{E}$ cross-sections have 11 neighbouring grid cells in two directions and there is a common grid cell, as can be seen in Figure 1. In the cross-section figures we show the built-up ratio and the annual mean maximum UHI intensity by grid cells along the two directions (Figure 5(a) and (b)).

In the eastern districts, detached and semi-detached houses with gardens are dominant; the ratio of the artificial surface cover is between 25 and $50 \%$. In the western parts, large housing estates with 10-14-storey buildings can be found. The ratio of the artificial surface cover is not very high (40-60\%), but the most extensive vertical active surfaces can be found here (Figure 5(b)). Since the houses in the city are built in $\mathrm{S}-\mathrm{N}$ rows, the distance between the buildings in that direction is very small (only a few metres), so they form quasi-homogeneous active surfaces oriented to the east and west. In the $\mathrm{S}-\mathrm{N}$ direction the imbalance is more visible than in the $\mathrm{W}-\mathrm{E}$ direction. In the southern part there is an industrial belt, where the ratio of
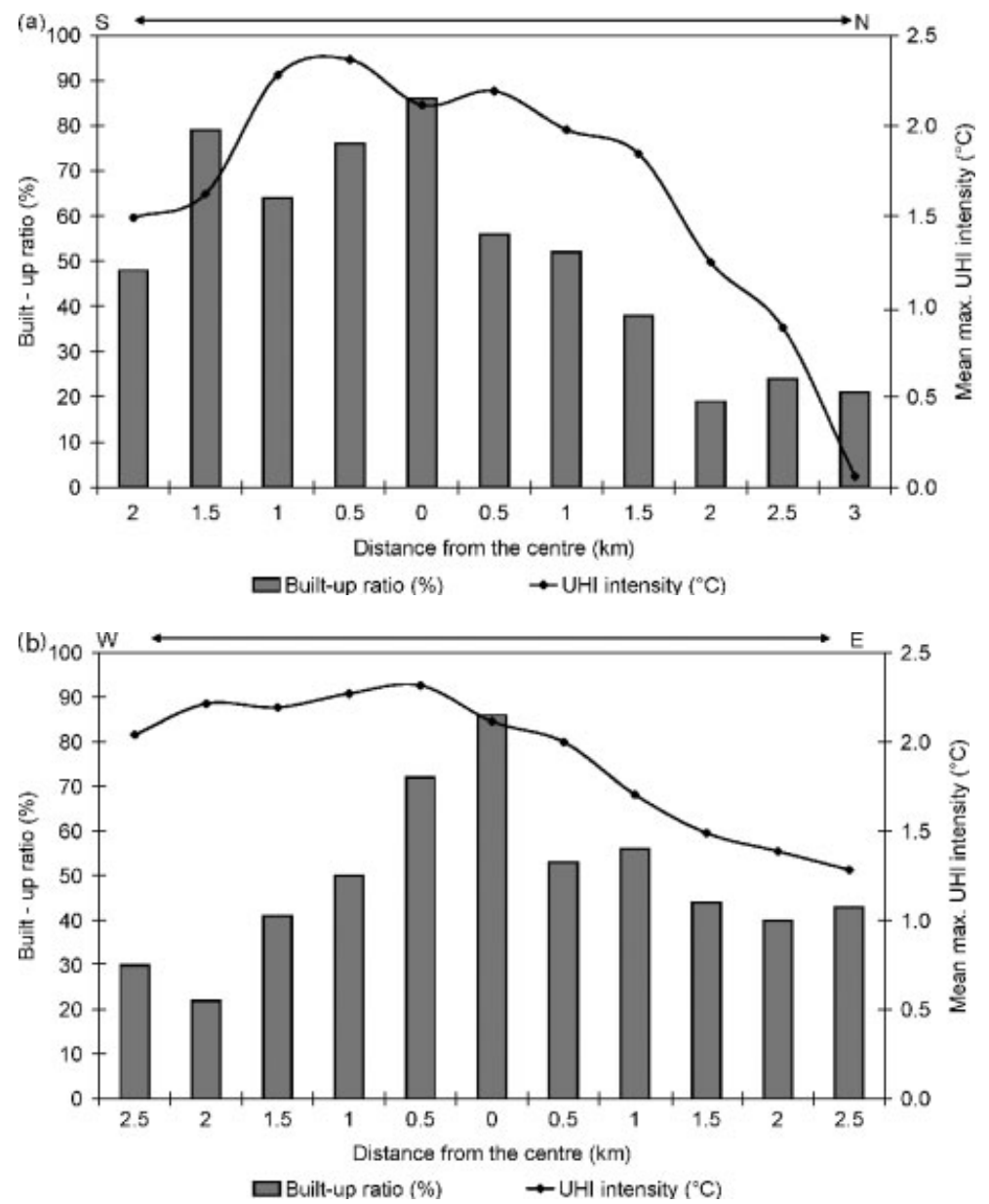

Figure 5. Relationship between built-up ration, distance from the city centre and annual mean maximum UHI intensities along cross-sections: (a) S-N cross-section; (b) W-E cross-section 
the artificial surface cover is relatively high (between 60 and 80\%). On the other hand, in the northern part there is a forest, which is the first nature conservation area in Hungary. Its urban part, which belongs to the study area, is an extensive park forest $\left(1.75 \mathrm{~km}^{2}\right)$ with recreation grounds, a stadium, an amusement park, a zoo, a hospital and the campus of the University of Debrecen (Figure 5(a)).

As the built-up ratio decreases rapidly from the central areas toward the northern outer regions, the UHI intensity also shrinks in this direction (Figure 2). We note that this spectacular decrease in UHI intensity in this direction is due to the wide area with a very low built-up ratio in the northern part of the city. On the other hand, the significant decrease in the built-up ratio from the city centre toward the western, outer part of the study area does not involve a similar strong decrease in the UHI intensity because these low-level built-up ratio values are not found within a wide area, but rather within a narrow local region (Figure 5(b)).

(3) In a number of places there are no clear borders between the city and its rural environment: the density of the covered surface decreases very gradually because patches of detached houses with gardens alternate with extensive green areas (the airbase, sporting grounds and forest) along the borders of the city. For example, this influence is well observed at the northern border of our investigation area, where both the UHI intensity and the built-up ratio decrease and the UHI intensity value is nearing zero (Figure 5(a)).

Measurements have proved the existence of the UHI in Debrecen. The annual mean maximum UHI intensity was $2.3^{\circ} \mathrm{C}$, but the strongest development of this phenomenon was $5.8^{\circ} \mathrm{C}(16$ June 2002$)$ in the study period.

The mean maximum UHI intensity reached $2.5^{\circ} \mathrm{C}$ in the non-heating season, which is a higher value than that of the heating season of $2.1^{\circ} \mathrm{C}$ (Figure 2). As can be seen, the spatial distribution of the mean maximum UHI intensity field has a concentric-like shape; however, the strongest intensity does not occur exactly in the centre of the investigation area, but it is not too far from this densely built-up area. In the non-heating half year the expansion of the $1{ }^{\circ} \mathrm{C}$ and $1.5^{\circ} \mathrm{C}$ isolines to the southeastern and southern regions of the city is caused by the relatively high built-up ratio of more than $60 \%$ (Figure 2(b)). However, UHI intensity increases gradually in the eastern parts of the city towards the centre because the built-up density grows gradually as well. The forested area in the north is the coolest part of the city. The highest horizontal gradients $\left(0.5^{\circ} \mathrm{C} / 300 \mathrm{~m}\right)$ were found there. This corresponds to the spatial pattern of the natural and artificial surfaces, i.e. the ratio of the artificial surface cover is under $30 \%$ in the urban part of the forest (Figure 2). This area is bordered by low-intensity residential areas, the hospital and the campus of the University of Debrecen. It is connected to the large forest outside the city in the north, and for this reason it is cooler than its urban environment by $0.5-0.8^{\circ} \mathrm{C}$ annually on average.

As we can see in Figure 2, the heat island is stronger in the non-heating season than in the heating season, but the spatial distribution of the urban heat excess is similar. This seasonal difference in temperature values was also observable in Lodz, Poland, and Szeged, Hungary (Klysik and Fortuniak, 1999; Unger et al., 2000).

\subsection{Statistical model equations}

Applying the model construction described in Section 2.4 two model equations, Equations (1) and (2), were determined to predict the mean maximum UHI intensity $\Delta T$ in the non-heating and the heating seasons, using the built-up ratio $B$ and its areal extensions $\left(B_{1}, B_{2}\right.$ and $\left.B_{3}\right)$ as predictors:

$$
\begin{aligned}
\Delta T_{\mathrm{nh}} & =2.258 B_{1}-3.242 B_{3}+2.065 \\
\Delta T_{\mathrm{h}} & =-4.240 B_{3}+1.252 B_{1}-1.537 B_{2}+3.281
\end{aligned}
$$

The order of the significance of our estimates is the same value $(0.1 \%)$, but the number of the predictors is different. The model equations for the non-heating and the heating seasons have two and three predictors respectively (Table III). $B_{1}$ and $B_{3}$ parameters are dominant in both model equations, and $B_{2}$ plays a less important role in the heating season. In the non-heating season the importance of the $B_{1}$ parameter can be well seen, because by applying the other significant predictor $\left(B_{3}\right)$ the model performance increases by only $3.1 \%$ in the fourth column $\left(\Delta r^{2}\right)$ of Table III. Then again, the role of the $B_{3}$ predictor is less dominant $\left(r^{2}=0.203\right)$ in the heating half year than the role of $B_{1}\left(r^{2}=0.315\right)$ in the non-heating season; therefore, it is necessary 
Table III. Values of the stepwise correlation of maximum UHI intensity $\Delta T$ and urban surface parameters $\left(B_{1}, B_{2}\right.$ and $\left.B_{3}\right)$ by grid cells and their significance levels in the two periods studied in Debrecen $(n=101)$

\begin{tabular}{lccccc}
\hline Period & Parameter entered & Multiple $|r|$ & Multiple $r^{2}$ & $\Delta r^{2}$ & Significance level (\%) \\
\hline 16 April-15 October (non-heating season) & $B_{1}$ & 0.561 & 0.315 & 0.000 & 0.1 \\
& $B_{1}, B_{3}$ & 0.588 & 0.346 & 0.031 & 0.1 \\
16 October-15 April (heating season) & $B_{3}$ & 0.451 & 0.203 & 0.000 & 0.1 \\
& $B_{3}, B_{1}$ & 0.505 & 0.255 & 0.052 & 0.1 \\
& $B_{3}, B_{1}, B_{2}$ & 0.552 & 0.305 & 0.050 & 0.1 \\
\hline
\end{tabular}

to use two other parameters in our estimate in the colder season. Nevertheless, the two predictors applied, $B_{1}$ $\left(\Delta r^{2}=0.052\right)$ and $B_{2}\left(\Delta r^{2}=0.050\right)$, increase the model performance by more than $10 \%$ in this period.

The multiple correlation coefficients $r$ between $\Delta T$ and the parameters studied are 0.552 and 0.588 in the heating and non-heating half years respectively. These correlation values mean that the urban parameter applied (i.e. built-up ratio) and its areal extensions are able to explain $34.6 \%$ and $30.5 \%$ of the foregoing connections in both seasons.

Referring to the study periods, Table IV contains the basic statistics of the model parameters. As the second column of Table IV shows, all of the above-mentioned parameters have good significance values, which are less than 0.05 in all cases. Table IV also presents the standard errors and the $95 \%$ confidence intervals of the model predictors.

The spatial distributions of the predicted $\Delta T$ patterns in the examined field of the city were determined by two model equations (Equations (1) and (2)). On comparing the predicted and the measured UHI intensity fields (Figures 2 and 6) there is a significant similarity between the spatial structures, but some differences can also be detected. To visualize the results better, we combined the measured and predicted UHI intensity fields (indicated with isolines) and the spatial distribution of built-up ratio (indicated with grey colour scale) in Figures 2 and 6. In both seasons the minimum measured $\Delta T$ value is in the northern part of the city, which also has the lowest built-up ratio. The minimum predicted UHI intensities can also be found in the same region. It needs to be noted that the predicted low $\Delta T$ values are higher than the measured ones in both half years, whereas high temperature values show an opposite trend. Thus, the predicted UHI intensity range is narrower than the measured one.

There is another difference between the structure of the measured and predicted temperature fields: the maximum values of the measured UHI intensities in both seasons are not exactly in the same area as the predicted maximum $\Delta T$ values. However, these maximum values occur in the neighbouring cells.

These above-mentioned differences are mainly caused by the geometry of the land-use features of the study area. The built-up ratio parameter applied does not contain enough information about the three-dimensional

Table IV. The values of the significance, coefficients, standard errors and $95 \%$ confidence intervals of the urban surface parameters applied in our models in the two periods studied in Debrecen $(n=101)$

\begin{tabular}{|c|c|c|c|c|c|c|}
\hline \multirow[t]{2}{*}{ Period } & \multirow[t]{2}{*}{ Parameter } & \multirow[t]{2}{*}{ Significance } & \multirow[t]{2}{*}{ Coefficient } & \multirow{2}{*}{$\begin{array}{c}\text { std. } \\
\text { error }\end{array}$} & \multicolumn{2}{|c|}{$95 \%$ confidence interval } \\
\hline & & & & & Lower bound & Upper bound \\
\hline \multirow{3}{*}{16 April-15 October (non-heating season) } & $B_{1}$ & 0.000 & 2.258 & 0.471 & 1.316 & 3.200 \\
\hline & $B_{3}$ & 0.033 & -3.242 & 1.497 & -6.236 & -0.248 \\
\hline & Constant & 0.014 & 2.065 & 0.823 & 0.419 & 3.711 \\
\hline \multirow[t]{4}{*}{16 October-15 April (heating season) } & $B_{3}$ & 0.000 & -4.240 & 1.075 & -6.390 & -2.090 \\
\hline & $B_{1}$ & 0.001 & 1.252 & 0.351 & 0.550 & 1.954 \\
\hline & $B_{2}$ & 0.010 & -1.537 & 0.584 & -2.705 & -0.369 \\
\hline & Constant & 0.000 & 3.281 & 0.669 & 1.943 & 4.619 \\
\hline
\end{tabular}




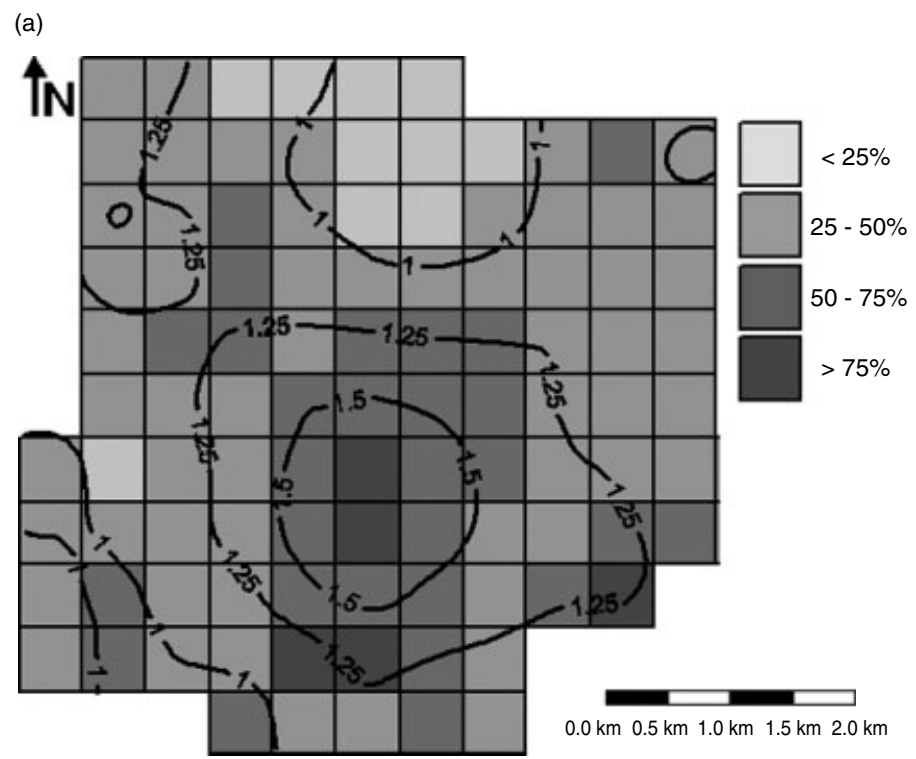

(b)

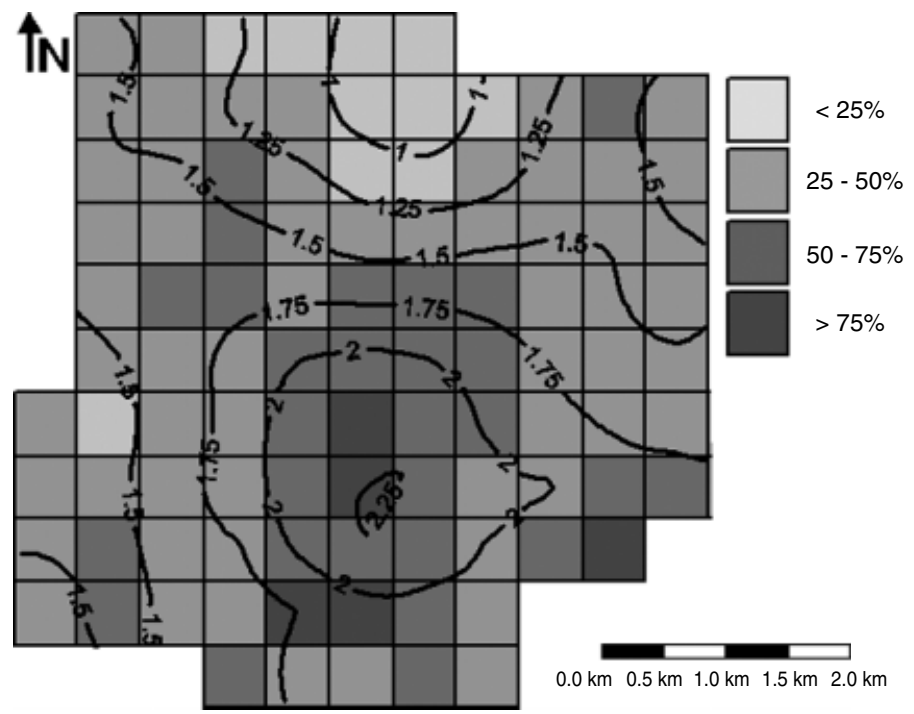

Figure 6. Spatial distribution of the predicted UHI intensity $\left({ }^{\circ} \mathrm{C}\right)$ and the built-up ratio (\%) in Debrecen: (a) heating season; (b) non-heating season

geometry of the city surface, which plays a key role in the radiation budget in the cities and so is partly responsible for the development and structure of the UHI (Eliasson, 1996; Sakakibara, 1996; Goh and Chang, 1999; Bottyán and Unger, 2003).

\section{CONCLUSIONS}

The mean maximum UHI intensity field has been investigated in the medium-sized Hungarian city of Debrecen. The area examined is situated on a plain, so there is an opportunity to derive some general statements on the modifying effects of urbanization on climate. Our conclusions are as follows: 
- The UHI phenomenon could be well observed in the study area, but its intensity changed during the period of investigation as a consequence of the prevailing weather conditions varying considerably by season in this climatic region.

- The spatial patterns of the measured mean maximum UHI intensity have a concentric-like shape and the values of the isotherms increase from the rural areas towards the central urban parts in the two study periods. The anomalies are caused by alterations in the urban surface factors.

- There are significant differences in the magnitudes of the seasonal patterns. The area of the mean maximum UHI intensity of higher than $2{ }^{\circ} \mathrm{C}$ (indicating significant thermal modification caused by urbanization) is 76 times larger in the non-heating season than in the heating season $(0.5 \%$ and $38 \%$ respectively). On the other hand, the strongest developments of UHI occurring in the warmer and colder periods were $5.8^{\circ} \mathrm{C}$ and $4.9^{\circ} \mathrm{C}$ respectively.

- On the basis of our statistical analysis, we have proved a strong linear relationship between the mean UHI intensity and the urban parameters studied, such as built-up ratio and its areal extensions, in both seasons. Generally, our model equations have described the spatial distribution of the real UHI intensity field in the study area generally correctly, although there are some (but not significant) differences between the predicted and measured UHI fields. These differences may be caused by some possible errors in the temperature samplings and the considerable irregularities of the three-dimensional surface geometry.

- Consequently, our results prove that the statistical approach on estimation of the UHI intensity field is promising. We are planning to extend this project by modelling urban thermal patterns as they are affected by other urban surface parameters (for instance sky-view factor, height/width aspect ratio, building volume and compactness) that describe the real city geometry better, with special regard to vertical structure, heat storage and heat transfer.

\section{ACKNOWLEDGEMENTS}

We wish to give special thanks to the students (Gábor Németh, Edina Bokor, Tamás Géczy, Anita Neutzer and Balázs Szécsi) who took part in the measurement campaigns and in the data preprocessing. The linguistic revision was made by E. Tanács. This research was supported by a grant from the Hungarian Scientific Research Fund (OTKA T/034161).

\section{REFERENCES}

Anon. 1992. Climatological normals (CLINO) for the period 1961-1990. WMO/OMM-No. 847.

Bottyán Z, Unger J. 2003. A multiple linear statistical model for estimating the mean maximum urban heat island. Theoretical and Applied Climatology 75: 233-243.

Comrie AC. 2000. Mapping a wind-modified urban heat island in Tucson, Arizona (with comments on integrating research with undergraduate learning). Bulletin of the American Meteorological Society 81: 2417-2431.

Eliasson I. 1996. Urban nocturnal temperatures, street geometry and land use. Atmospheric Environment 30: $379-392$.

Gallo KP, Owen TW. 1999. Satellite-based adjustments for the urban heat island temperature bias. Journal of Applied Meteorology 38: $806-813$.

Goh KC, Chang CH. 1999. The relationship between height to width ratios and the heat island intensity at $22: 00 \mathrm{~h}$ for Singapore. International Journal of Climatology 19: 1011-1023.

Grimmond CSB, Oke TR. 1991. An evapotranspiration-interception model for urban areas. Water Resources Research 27: $1739-1755$.

Grimmond CSB, Cleugh HA, Oke TR. 1991. An objective urban heat storage model and its comparison with other schemes. Atmospheric Environment B 25: 311-326.

Grimmond CSB, Potter SK, Zutter HN, Souch C. 2001. Rapid methods of estimate sky-view factors applied to urban areas. International Journal of Climatology 21: 903-913.

Johnson DB. 1985. Urban modification of diurnal temperature cycles in Birmingham. Journal of Climatology 5: $221-225$.

Johnson GT, Oke TR, Lyons TJ, Steyn DG, Watson ID, Voogt JA. 1991. Simulation of surface urban heat islands under 'ideal' conditions at night, I: theory and tests against field data. Boundary Layer Meteorology 56: 275-294.

Kircsi A, Szegedi S. 2003. The development of the urban heat island studied on temperature profiles in Debrecen. Acta Climatologica et Chorologica Universitatis Szegediensis 36-37: 63-69.

Klysik K, Fortuniak K. 1999. Temporal and spatial characteristics of the urban heat island of Lódz, Poland. Atmospheric Environment 33: $3885-3895$.

Kuttler W. 1998. Stadtklima. In Stadtökologie, Sukopp H, Wittig R (eds). Gustav Fisher: Stuttgart; $125-167$.

Kuttler W, Barlag A-B, Roßmann F. 1996. Study of the thermal structure of a town in a narrow valley. Atmospheric Environment 30: 365-378.

Landsberg HE. 1981. The Urban Climate. Academic Press: New York. 
Matzarakis A, Beckröge W, Mayer H. 1998. Future perspectives in applied urban climatology. Proceedings of the Second Japanese-German Meeting, Kobe University; 109-122.

Miller AJ. 2002. Subset Selection in Regression. Chapman \& Hall/CRC: Boca Raton.

Montavez JP, Rodriguez A, Jimenez JI. 2000. A study of urban heat island of Granada. International Journal of Climatology 20: 899-911.

Moreno-Garcia MC. 1994. Intensity and form of the urban heat island in Barcelona. International Journal of Climatology 14: 705-710.

Mucsi L. 1996. Urban land use investigation with GIS and RS methods. Acta Geographica Szegediensis 25: 111-119.

Myrup LO, McGinn CE, Flocchini RG. 1993. An analysis of microclimatic variation in a suburban environment. Atmospheric Environment B 27: 129-156.

Oke TR. 1981. Canyon geometry and the nocturnal urban heat island: comparison of scale model and field observations. Journal of Climatology 1: 237-254.

Oke TR. 1988. Street design and urban canopy layer climate. Energy and Buildings 11: 103-113.

Oke TR, Fuggle RF. 1972. Comparison of urban/rural counter and net radiation at night. Boundary-Layer Meteorology 2: 290-308.

Oke TR, Maxwell GB. 1975. Urban heat island dynamics in Montreal and Vancouver. Atmospheric Environment 9: 191-200.

Outcalt SI. 1972. A synthetic analysis of seasonal influences in the effects of land use on the urban thermal regime. Archives for Meteorology, Geophysics and Bioclimatology, Series B: Theoretical and Applied Climatology 20: 253-260.

Park H-S. 1986. Features of the heat island in Seoul and its surrounding cities. Atmospheric Environment 20: $1859-1866$.

Ruffieux D. 1995. Winter surface energy budget in Denver, Colorado. Atmospheric Environment 29: 1579-1587.

Sakakibara Y. 1996. A numerical study of the effect of urban geometry upon the surface energy budget. Atmospheric Environment 30: 487-496.

Szegedi S. 2000. Spatial structure of urban heat island in Debrecen. In 3rd European Conference on Applied Climatology, Pisa, Italy, 16-20 October; CD-ROM.

Szegedi S, Kircsi A. 2003. The effects of the synoptic conditions on development of the urban heat island in Debrecen, Hungary. Acta Climatologica et Chorologica Universitatis Szegediensis 36-37: 111-120.

Tapper PD, Tyson PD, Owens IF, Hastie WJ. 1981. Modeling the winter urban heat island over Christchurch. Journal of Applied Meteorology 20: 365-367.

Unger J. 1999. Urban-rural air humidity differences in Szeged. International Journal of Climatology 19: 1509-1515.

Unger J, Bottyán Z, Sümeghy Z, Gulyás Á. 2000. Urban heat island development affected by urban surface factors. Idöjárás 104: $253-268$.

Unger J, Sümeghy Z, Gulyás Á, Bottyán Z, Mucsi L. 2001a. Land-use and meteorological aspects of the urban heat island. Meteorological Applications 8: 189-194.

Unger J, Sümeghy Z, Zoboki J. 2001b. Temperature cross-section features in an urban area. Atmospheric Research 58: 117-127.

Voogt JA, Grimmond CSB. 2000. Modeling surface sensible heat flux using surface radiative temperatures in a simple urban area. Journal of Applied Meteorology 39: 1679-1699.

Voogt JA, Oke TR. 1991. Validation of an urban canyon radiation model for nocturnal long-wave radiative fluxes. Boundary-Layer Meteorology 54: 347-361.

Voogt JA, Oke TR. 1997. Complete urban surface temperatures. Journal of Applied Meteorology 36: 1117-1132.

Yamashita S. 1996. Detailed structure of heat island phenomena from moving observations from electric tram-cars in metropolitan Tokyo. Atmospheric Environment 30: 429-435. 